\title{
Protocol for Collection, Culture, and Characterization of Human Skin Stem Cells
}

\author{
Anil Kumar ${ }^{1,}{ }^{*}$, Somesh Gupta ${ }^{2}$ and Sujata Mohanty ${ }^{3}$ \\ ${ }^{1}$ Amity Institute of Biotechnology, Amity University Haryana, Gurgaon 122413, India \\ ${ }^{2}$ Department of Dermatology and Venereology, All India Institute of Medical Sciences, New Delhi-110029, India \\ ${ }^{3}$ Stem Cell Facility, Centre of Excellence for Stem Cell Research, All India Institute of Medical Sciences, New Delhi, 110029, India \\ "Corresponding author: Assistant Professor, Amity Institute of Biotechnology, Amity University Haryana, Gurgaon 122413, India. Tel: +91-8130925418, Email: \\ anil.stem@gmail.com
}

Received 2019 November 29; Revised 2020 January 21; Accepted 2020 February 26.

\begin{abstract}
Background: Stem cells with their tremendous differentiation and trans-differentiation potential are the cells with many applications in degenerative disease management. Isolation, characterization, and differentiation are the areas that are most widely investigated to take the cells in clinical settings. Among many sources of stem cells, the skin is getting special attention because it is one of the most easily accessible tissues and has high differentiation potential.

Methods: We have given a detailed description of skin tissue collection, processing, and cell culture. The RNA isolation and cell proliferation by the MTT assay have also been elaborated.

Discussion: All the protocols detailed here were standardized in the All India Institute of Medical Sciences (AIIMS), New Delhi. We hope the protocols will be of help to those who initiate studies of skin stem cells and new investigators who may come up with further modifications. This will benefit advancement in this field.
\end{abstract}

Keywords: Human Skin Stem Cells, Stem Cell Culture, Stem Cell Characterization

\section{Background}

This article is the summary of the successful culture of human skin stem cells in the laboratory and their characterization at the All India Institute of Medical Sciences (AIIMS), New Delhi, India. This article will be of great help to the beginners working in the area of human skin stem cell, regenerative biology, and tissue engineering. It may also have a variety of other applications.

\section{Methods}

\subsection{Collection of Skin Tissue}

Healthy pigmented skin tissues were collected from children admitted for circumcision at the Department of Pediatric Surgery, AIIMS.

\subsection{Foreskin Tissue Collection}

The foreskin was circumcised following the injection of the local anesthetic in a cleanroom facility at the Department of Pediatric Surgery, AIIMS, and collected in a sterile vial. The vials containing foreskins were kept in a cool pack $\left(4^{\circ} \mathrm{C}\right)$ and transported to the laboratory under sterile conditions. The size of the foreskin tissue biopsy was approximately $2.5 \mathrm{~cm} \times 2.5 \mathrm{~cm}$.

\subsection{Processing of Foreskin Tissue}

The foreskin tissue was incubated overnight at $4^{\circ} \mathrm{C}$ in the $10 \mathrm{mg} / \mathrm{mL}$ dispase enzyme (17105-041 Gibco, NY, USA) obtained from Bacillus polymyxa. The dispase enzyme acts on the basement membrane, i.e., the junction of dermis and epidermis. The basement membrane zone has collagen and fibronectin connections. Having collagenase and fibronectinase activity, dispase dissociates the basement membrane so that the epidermis can be separated from the dermis.

After incubation, the epidermal layer was easily peeled off from the dermis. The dermis was scratched with the blunt face of the scalpel blade to collect basal layer cells, which might be sticking on the dermal surface. The dermis was discarded, and the epidermis was washed three times with phosphate-buffered saline (PBS) for 20 min each. The epidermis was placed into a Petri plate and then, using a scalpel blade (No. 22, Glass Van, India), it was chopped into small pieces of approximately $2 \mathrm{~mm} \times 2 \mathrm{~mm}$ size. Some of 
the chopped pieces were used for explant culture. The rest of the chopped pieces were trypsinized to prepare singlecell suspensions.

To prepare single-cell suspensions, chopped pieces were trypsinized (0.25\% trypsin and $0.05 \%$ EDTA) at $37^{\circ} \mathrm{C}$ in a carbon dioxide incubator for $20-25 \mathrm{~min}$. The tube was vortexed twice (for five seconds each) during the incubation period to aid mechanical dissociation. The action of trypsin was neutralized by adding an equal volume of trypsin inhibitor solution (T6522 Sigma, USA). The solution was further added with $5 \mathrm{~mL}$ of PBS and filtered through a $70-\mu$ m cell strainer (Becton Dickinson, Sunnyvale, CA, USA). The filtrate was centrifuged at $200 \mathrm{~g}$ for $5 \mathrm{~min}$ to obtain the cell pellet and then reconstituted in PBS $(1 \mathrm{~mL})$.

\subsection{Viable Cell Count in Cell Suspension Prepared from Skin Epi- dermis}

The trypan blue dye (TC L005, Hi-Media, Mumbai, India) was used to check the viability of cells. Trypan blue is expelled out by viable cells. As the trypan blue dye cannot penetrate the live cells, they appear bright, and the dead cells, which take up the dye, appear blue under the bright field microscope.

Equal volumes of the trypan blue dye and cell suspension were mixed and examined microscopically (ECLIPSE, E200, Nikon, Japan) after 3-min incubation. Then, $10 \mu \mathrm{L}$ of trypan blue cell mixture was loaded on the countess cell count loading slide (C10228, Invitrogen, NY, USA). The live and dead cells were encircled by blue and red colors, respectively, by countess software.

$\%$ Viability $=\frac{\text { Viable Cell Count }}{\text { Total Cell Count }} \times 100$

\subsection{Suspension Culture of Skin Stem Cells}

Cells obtained after trypsinization were seeded onto a culture dish at a density of 5,000 cells $/ \mathrm{cm}^{2}$ area of the culture dish coated with fibronectin (F2006, Sigma, MO, USA) at a concentration of $1 \mu \mathrm{g} / \mathrm{mL}$ in PBS. The culture dish was added with $1.5 \mathrm{~mL}$ of skin stem cell culture medium and incubated in a $5 \% \mathrm{CO}_{2}$ incubator at $37^{\circ} \mathrm{C}$. The culture medium was changed every three days.

\subsection{Fibronectin Coating}

The culture dish and the flasks to be coated were incubated with fibronectin at a concentration of $1 \mu \mathrm{g} / \mathrm{mL}$ for two hours at room temperature. After incubation, the fibronectin solution was removed from the culture flask and culture dish. The culture dishes and flasks were washed with PBS, air-dried, and kept at room temperature for further use.

\subsection{Culture Media Composition}

The skin stem cells culture media consisted of 3:1, Dulbecco's Modified Eagle's Medium (DMEM) and Ham's F12 nutrient mix (Sigma, MO, USA), supplemented with 10\% fetal bovine serum (Hyclone, NJ, USA), $10 \mathrm{ng} / \mathrm{ml}$ epidermal growth factor (PeproTech, NJ, USA), $2.8 \mu \mathrm{g} / \mathrm{mL}$ hydrocortisone, $5 \mu \mathrm{g} / \mathrm{mL}$ insulin, $10 \mu \mathrm{g} / \mathrm{mL}$ transferrin (Sigma, MO, USA), $10 \mathrm{ng} / \mathrm{mL}$ cholera toxin (Millipore, MA, USA), $100 \mathrm{U} / \mathrm{mL}$ penicillin, and $100 \mu \mathrm{g} / \mathrm{mL}$ streptomycin (Gibco, Tokyo, Japan)

\subsection{Explant Culture of Skin Stem Cells}

The chopped pieces of the skin epidermis, prepared, as stated above, were used for the explant culture of skin stem cells. About nine explants (approximately one skin explant $/ \mathrm{cm}^{2}$ area of the culture dish) were placed in a 35mm culture dish. Initially, a small volume of media was added to avoid the floating of the explants. After $6-8 \mathrm{~h}$, approximately $1.5 \mathrm{~mL}$ of epidermal stem cell culture media was added slowly to avoid explant floating. The culture dish was incubated in a $5 \% \mathrm{CO}_{2}$ incubator at $37^{\circ} \mathrm{C}$. The media were changed every three days.

\subsection{Feeder Layer Culture of Skin Stem Cells}

Skin stem cells were seeded over the feeder layer of 3T3 mouse fibroblasts at a density of 5,000 cells $/ \mathrm{cm} 2$. The culture dish was incubated at $37^{\circ} \mathrm{C}$ in a $\mathrm{CO}_{2}$ incubator. The media were changed every three days.

\subsection{Expansion of In Vitro Cultured Skin Stem Cells}

Skin stem cells at $70 \%$ - $80 \%$ confluence were trypsinized and re-plated for expansion in vitro. The epidermal stem cells culture media were aspirated out, and the adherent cells were washed with PBS. After washing, PBS was aspirated, and $150 \mu \mathrm{L}$ of $0.25 \%$ trypsin $-0.05 \%$ EDTA solution (25200056 ThermoFisher, USA) was added to $35-\mathrm{mm}$ dishes, and then incubated at room temperature for $5 \mathrm{~min}$. The culture flask was given the mechanical force (tapped with index finger) between the incubation periods to dislodge adherent cells. The flask was observed under an inverted microscope (Eclipse Ti, Nikon, Japan) to visualize the full dislodgement of cells. Once the cells were fully dislodged, a trypsin inhibitor (T6522 Sigma, USA) in the volume equal to that of trypsin EDTA (25200056 ThermoFisher, USA) was added. The cell suspension was collected in a $1.5-\mathrm{mL}$ centrifuge tube and centrifuged at $200 \mathrm{~g}$ for $5 \mathrm{~min}$ to obtain the cell pellet. The supernatant was discarded, and the cell pellet was reconstituted in PBS. Finally, cells were counted for number and viability by the trypan blue dye exclusion method. The cells were passaged at a split ratio of 1:3. 


\subsection{Characterization of Skin Stem Cells:}

\subsubsection{Methodology of Total RNA Isolation from Expanded Skin Stem Cells}

Confluent cultures of EpiSC growing in T25 flasks were trypsinized. The collected cells were centrifuged at $200 \mathrm{~g}$ to pellet down the cells. Cells were transferred to $1.5-\mathrm{mL}$ centrifuge tubes. Then, $1000 \mu \mathrm{L}$ of Tri Reagent (TR118, MRC, USA) was added to the cell pellet, triturated with a pipette for $10 \mathrm{~min}$, and incubated at room temperature for $5 \mathrm{~min}$. After incubation, $200 \mu \mathrm{L}$ of chloroform was added, hand vortexed for $30 \mathrm{~s}$, and incubated at room temperature for 3 min. After incubation, the tube was centrifuged at 12,000 $\mathrm{g}$ for $15 \mathrm{~min}$ at $4^{\circ} \mathrm{C}$. Centrifugation separated the aqueous phase and organic phase, with RNA remaining in the aqueous phase. The aqueous phase was taken carefully into a fresh 1.5 -mL centrifuge tube, followed by adding $500 \mu \mathrm{L}$ of isopropyl alcohol and incubating at room temperature for $10 \mathrm{~min}$. After incubation, the tube was centrifuged at $12,000 \mathrm{~g}$ for $10 \mathrm{~min}$ at $4^{\circ} \mathrm{C}$. Isopropyl alcohol precipitated the RNA, and a transparent pellet was formed. The supernatant was discarded, and the pellet was washed with $75 \%$ ethanol by centrifugation at 7,000 $\mathrm{g}$ for $5 \mathrm{~min}$ at $4^{\circ} \mathrm{C}$. The RNA pellet was air-dried, dissolved in $20 \mu \mathrm{L}$ of nuclease-free water (ML024, Himedia, India), and stored at $-80^{\circ} \mathrm{C}$.

\subsubsection{Quantification of Total RNA}

The RNA was quantified using a nanophotometer (Implen, Germany). First, a blank was set for RNA using nuclease-free water. Then, $1 \mu \mathrm{l}$ of RNA was placed in the lid factor of 50 and mounted on the holder. The absorbance was measured at 260 and $280 \mathrm{~nm}$. The quantity of RNA per $\mu \mathrm{L}$ of the solution was calculated using nanophotometer software.

\subsubsection{Preparation of cDNA from Total RNA (Reverse Transcrip- tase PCR)}

In this method, $1 \mu \mathrm{g}$ of RNA was taken, and $0.5 \mu \mathrm{g}$ of the oligo (dT)18 primer was added to the reaction mixture. Then, DEPC water (HiMedia, India) was added to reach a volume of $15 \mu \mathrm{L}$ and incubated at $70^{\circ} \mathrm{C}$ for 5 min to break RNA secondary structures. After incubation, the sample was snap chilled to stop the formation of RNA secondary structures. Next, the following components were added to the primary mixture: $4.0 \mu \mathrm{L}$ RiboLock RNase Inhibitor (EO0381, Thermofisher, USA), $0.5 \mu \mathrm{L}$ (20 units) dNTP mix (10 mM each) (U1511, Promega, USA), and $2.5 \mu \mathrm{L}$ (1 mM final conc.) M-MuLV RT enzyme (M1701, Promega, USA).

Finally, $1 \mu \mathrm{L}$ (200 units) DEPC water (ML024, Himedia, India) was added to make up the total volume of $25 \mu \mathrm{L}$. The total reaction mixture was incubated at $42^{\circ} \mathrm{C}$ for $60 \mathrm{~min}$ and finally at $72^{\circ} \mathrm{C}$ for $10 \mathrm{~min}$ to terminate the reaction.
The PCR was performed following standard protocols in a $25-\mu \mathrm{L}$ reaction mixture volume with sequence-specific primers (sequence of primers) (DNA Engine, BIO-RAD, USA). The $25-\mu \mathrm{L}$ reaction volume included $0.5 \mu \mathrm{L}$ dNTPs (10 $\mathrm{mM}$ ) (U1511, Promega, USA), $2.0 \mu \mathrm{L} \mathrm{MgCl}_{2}$ (25 mM) (A3511, Promega, USA), $2.0 \mu$ L Taq Buffer (10X) (M8901, Promega, USA), $2.0 \mu \mathrm{L}$ primers ( $1 \mu \mathrm{L}$ Forward $+1 \mu \mathrm{L}$ Reverse), $0.2 \mu \mathrm{L}$ Taq polymerase (M8291 Promega, USA), and $1.0 \mu \mathrm{L}$ cDNA. Nuclease free water (ML024, Himedia, India) was added to make the final volume of $20 \mu \mathrm{L}$. All reagents were added in 0.2-mL PCR tubes and reactions were performed under the following PCR conditions: Initial denaturation at $94^{\circ} \mathrm{C}$ for 5 min, denaturation at $94^{\circ} \mathrm{C}$ for $1 \mathrm{~min}$, primer-specific annealing, extension at $72^{\circ} \mathrm{C}$ for $1 \mathrm{~min}$ to $1.5 \mathrm{~min}$, and a final extension at $72^{\circ} \mathrm{C}$ for $7 \mathrm{~min}$.

The expression of respective gene transcripts was quantified relatively. The cDNA concentration of samples was optimized to equilibrate the GAPDH expression in each batch of samples. Electrophoresis (Bio-Rad, USA) was performed by loading $10-\mu \mathrm{l}$ PCR products on a $2 \%$ agarose gel (Himedia, India) with ethidium bromide to check gene expression, followed by visualizing in the gel documentation system (Alpha DigiDoc, ImageTech, USA).

\subsection{Cell Proliferation Assay}

A 96-well culture plate was used to culture skin stem cells $(5,000$ cells/well) with skin stem cell culture media. The MTT (3-(4,5-Dimethylthiazol-2-yl)-2,5diphenyltetrazolium bromide) assay was done on days 1,3, $5,7,10$, and 12. $50 \mu \mathrm{L}$ of the MTT reagent ( $5 \mathrm{mg} / \mathrm{mL}$ in PBS) was added to the wells in triplicate and incubated at $37^{\circ} \mathrm{C}$ for $3.5 \mathrm{~h}$. After incubation, formazan crystals were formed that were dissolved by adding $300 \mu \mathrm{L}$ of dimethylsulfoxide (D4540 Sigma, USA) to each well. A new 96-well culture plate was used to read the colored solution at $570 \mathrm{~nm}$ in a plate reader (EL 800, Biotek, USA).

\subsection{Ethical Clearance}

Studies that involve human subjects need ethical clearance from the Institutional Human Ethics Committee and the Stem Cell Ethics Committee of the Institute, in coordination with the National Ethics Committee or as per the ethical guidelines of the country in which the Institute is located. At the AIIMS, New Delhi, we needed to take permission from the Institutional Ethics Committee (IEC) and the Institutional Committee for Stem Cell Research (IC-SCR). Tissue samples were collected after getting informed consent of the patients, approved by the IEC and IC-SCR of AIIMS. The IC-SCR needs to provide all the data related to ethical practices followed to the National Apex Committee for Stem Cell Research and Therapy (NAC-SCRT). 


\section{Discussion}

This study aimed to establish a protocol for the culture and characterization of epidermal stem cells of human skin origin. These cells have huge potential in clinical settings and research on the basic biology of stem cells (15). The foreskin tissue is widely used for skin cell culture. The foreskin and facial biopsy were used by Eisinger and Marko for the culture of melanocytes in vitro, as followed by several other scientific groups (6-11).

For the culture and expansion of skin, three prevailing methodologies are adopted: (I) suspension culture over fibronectin-coated plates, (II) explant culture over fibronectin-coated plates, and (III) feeder layer culture over 3T3 fibroblast. The suspension culture of skin cells has also been tried previously for the generation of skin spheres and hair spheres $(12,13)$. Recently, the suspension culture has been used for the culture of Dermal Stem Cells (DSCs) (14-16). The use of feeder cells in the cell culture was first reported by Puck et al. (17). The successful culture of human keratinocytes was pioneered by Rheinwald over the feeder layer of murine 3T3 fibroblasts. Rheinwald reported that the culture of keratinocytes over the 3T3 feeder layer enhanced the growth (18-21). Balasubramanian et al. showed that the culture of limbal corneal epithelial cells over murine 3T3 feeder cells enhanced the stemness for longer periods in-vitro (22). Moreover, hair follicle explant culture was reported by Zhang et al. (23).

There is no definitive marker to characterize epidermal stem cells of the skin. The lack of specific markers has been a major obstacle $(24,25)$ in the characterization of skin stem cells. Therefore, a panel of markers should be employed for skin stem cell characterization by immunofluorescence and RT-PCR (12, 21, 26-35).

The field of skin stem cell identification, characterization, and application has shown great progress in regenerative biology and tissue engineering due to the ease of skin tissue access and development of tissue culture techniques, but still, many queries need to be answered. Skin stem cells are being employed in the management of pigment disorder and burns by expanding small biopsies into a large number of cells, thereby covering a large surface area of the affected skin (36). The cultured skin stem cells are also being used in genetic engineering experiments, which is opening its way in the management of various genetic disorders (37-39).

With recent developments in the field of animal cell culture and tissue engineering, skin stem cells are being employed in a wide variety of applications. These novel technological approaches will further enhance our understanding of the basic and applied biology of skin stem cells, which will open unlimited possibilities in the ad- vancement of regenerative biology and technology development.

\section{Acknowledgments}

We acknowledge the Department of Pediatric Surgery of AIIMS, New Delhi, for providing foreskin samples.

\section{Footnotes}

Authors' Contribution: Laboratory work was done by Anil Kumar. Somesh Gupta, Sujata Mohanty, and Anil Kumar designed the study.

Conflict of Interests: None.

Ethical Approval: The project was approved by the $\mathrm{Hu}$ man Ethics Committee and the Institutional Committee of Stem Cell Research, AIIMS, New Delhi, India.

Funding/Support: The project was supported in part by the Department of Biotechnology, IADVL-Lo'real, and AIIMS, New Delhi.

Informed Consent: Patient informed consent was taken. Patient information sheet and informed consent form are attached as Appendices.

\section{References}

1. Dai R, Hua W, Xie H, Chen W, Xiong L, Li L. The human skin-derived precursors for regenerative medicine: Current state, challenges, and perspectives. Stem Cells Int. 2018;2018:8637812. doi: 10.1155/2018/8637812. [PubMed: 30123295]. [PubMed Central: PMC6079335].

2. Yang R, Liu F, Wang J, Chen X, Xie J, Xiong K. Epidermal stem cells in wound healing and their clinical applications. Stem Cell Res Ther. 2019;10(1):229. doi: 10.1186/s13287-019-1312-z. [PubMed: 31358069]. [PubMed Central: PMC6664527].

3. Wong VW, Levi B, Rajadas J, Longaker MT, Gurtner GC. Stem cell niches for skin regeneration. Int J Biomater. 2012;2012:926059. doi: 10.1155/2012/926059. [PubMed: 22701121]. [PubMed Central: PMC3371691].

4. Pushp P, Sahoo B, Ferreira FC, Sampaio Cabral JM, FernandesPlatzgummer A, Gupta MK. Functional comparison of beating cardiomyocytes differentiated from umbilical cord-derived mesenchy$\mathrm{mal} /$ stromal stem cells and human foreskin-derived induced pluripotent stem cells. J Biomed Mater Res A. 2020;108(3):496-514. doi: 10.1002/jbm.a.36831. [PubMed: 31707752].

5. Ejaz A, Hatzmann FM, Hammerle S, Ritthammer H, Mattesich M, Zwierzina $\mathrm{M}$, et al. Fibroblast feeder layer supports adipogenic differentiation of human adipose stromal/progenitor cells. Adipocyte. 2019;8(1):178-89. doi: 10.1080/21623945.2019.1608751. [PubMed: 31033380]. [PubMed Central: PMC6768258].

6. Eisinger M, Marko O. Selective proliferation of normal human melanocytes in vitro in the presence of phorbol ester and cholera toxin. Proc Natl Acad Sci U S A. 1982;79(6):2018-22. doi: 10.1073/pnas.79.6.2018. [PubMed: 6952249]. [PubMed Central: PMC346113].

7. Eves PC, Beck AJ, Shard AG, Mac Neil S. A chemically defined surface for the co-culture of melanocytes and keratinocytes. Biomaterials. 2005;26(34):7068-81. doi: 10.1016/j.biomaterials.2005.05.015. [PubMed: 15979140]. 
8. Ghosh D, Shenoy S, Kuchroo P. Cultured melanocytes: from skin biopsy to transplantation. Cell Transplant. 2008;17(3):351-60. doi: 10.3727/096368908784153869. [PubMed: 18522237].

9. Neitmann M, Alexander M, Brinckmann J, Schlenke P, Tronnier M. Attachment and chemotaxis of melanocytes after ultraviolet irradiation in vitro. Br J Dermatol. 1999;141(5):794-801. doi: 10.1046/j.13652133.1999.03151.x. [PubMed: 10583159].

10. Watt FM, Jordan PW, O'Neill CH. Cell shape controls terminal differentiation of human epidermal keratinocytes. Proc Natl Acad Sci U S A. 1988;85(15):5576-80. doi: 10.1073/pnas.85.15.5576. [PubMed: 2456572] [PubMed Central: PMC281801].

11. Oliveira T, Costa I, Marinho V, Carvalho V, Uchôa K, Ayres C, et al. Human foreskin fibroblasts: From waste bag to important biomedical applications. J Clin Urol. 2018;11(6):385-94. doi: $10.1177 / 2051415818761526$.

12. Yu H, Fang D, Kumar SM, Li L, Nguyen TK, Acs G, et al. Isolation of a novel population of multipotent adult stem cells from human hair follicles. Am J Pathol. 2006;168(6):1879-88. doi: 10.2353/ajpath.2006.051170. [PubMed: 16723703]. [PubMed Central: PMC1606635].

13. Toma JG, Akhavan M, Fernandes KJ, Barnabe-Heider F, Sadikot A, Kaplan DR, et al. Isolation of multipotent adult stem cells from the dermis of mammalian skin. Nat Cell Biol. 2001;3(9):778-84. doi: 10.1038/ncb0901-778. [PubMed: 11533656].

14. Li L, Fukunaga-Kalabis M, Yu H, Xu X, Kong J, Lee JT, et al. Human dermal stem cells differentiate into functional epidermal melanocytes. J Cell Sci. 2010;123(Pt 6):853-60. doi: 10.1242/jcs.061598. [PubMed: 20159965]. [PubMed Central: PMC2831759].

15. Li L, Fukunaga-Kalabis M, Herlyn M. Isolation and cultivation of dermal stem cells that differentiate into functional epidermal melanocytes. Methods Mol Biol. 2012;806:15-29. doi: 10.1007/978-161779-367-7 2. [PubMed: 22057442].

16. Zabierowski SE, Fukunaga-Kalabis M, Li L, Herlyn M. Dermis-derived stem cells: A source of epidermal melanocytes and melanoma? Pigment Cell Melanoma Res. 2011;24(3):422-9. doi: 10.1111/j.1755148X.2011.00847.x. [PubMed: 21410654].

17. Puck TT, Marcus PI, Cieciura SJ. Clonal growth of mammalian cells in vitro; growth characteristics of colonies from single HeLa cells with and without a feeder layer. J Exp Med. 1956;103(2):27383. doi: 10.1084/jem.103.2.273. [PubMed: 13286432]. [PubMed Central PMC2136583].

18. Rheinwald JG, Green H. Serial cultivation of strains of human epidermal keratinocytes: The formation of keratinizing colonies from single cells. Cell. 1975;6(3):331-43. doi: 10.1016/s0092-8674(75)80001-8. [PubMed: 1052771].

19. Rheinwald JG. Serial cultivation of normal human epidermal keratinocytes. Methods Cell Biol. 1980;21A:229-54. doi: 10.1016/s0091679x(08)60769-4. [PubMed: 6157968].

20. Blacker KL, Williams ML, Goldyne M. Mitomycin C-treated 3T3 fibroblasts used as feeder layers for human keratinocyte culture retain the capacity to generate eicosanoids. J Invest Dermatol. 1987;89(6):536-9. doi: 10.1111/1523-1747.ep12461169. [PubMed: 3119730].

21. Zhou JX, Chen SY, Liu WM, Cao YJ, Duan EK. Enrichment and identification of human 'fetal' epidermal stem cells. Hum Reprod. 2004;19(4):968-74. doi: 10.1093/humrep/deh166. [PubMed: 15016782].

22. Balasubramanian S, Jasty S, Sitalakshmi G, Madhavan HN, Krishnakumar S. Influence of feeder layer on the expression of stem cell markers in cultured limbal corneal epithelial cells. Indian J Med Res. 2008;128(5):616-22. [PubMed: 19179682].

23. Zhang Y, Xiang M, Wang Y, Yan J, Zeng Y, Yu J, et al. Bulge cells of human hair follicles: segregation, cultivation and properties. Colloids Surf B Biointerfaces. 2006;47(1):50-6. doi:10.1016/j.colsurfb.2005.11.017. [PubMed: 16387478].

24. Lavker RM, Sun TT. Epidermal stem cells: Properties, markers, and location. Proc Natl Acad Sci U S A. 2000;97(25):13473-5. doi 10.1073/pnas.250380097. [PubMed: 11087834]. [PubMed Central: PMC34083].

25. Tani H, Morris RJ, Kaur P. Enrichment for murine keratinocyte stem cells based on cell surface phenotype. Proc Natl Acad Sci U S A. 2000;97(20):10960-5. doi: 10.1073/pnas.97.20.10960. [PubMed: 11005869]. [PubMed Central: PMC27131].

26. Zhou HJ, Hu ZQ, Tan T, Sun XJ. [Effective isolation and culture of the outer root sheath bulge cells, dermal sheath cells and dermal papilla cells derived from human hair follicle]. Nan Fang Yi Ke Da Xue Xue Bao. 2008;28(2):193-5. Chinese. [PubMed: 18250040].

27. Zhou MN, Zhang ZQ, Wu JL, Lin FQ, Fu LF, Wang SQ, et al. Dermal mesenchymal stem cells (DMSCs) inhibit skin-homing CD8+ T cell activity, a determining factor of vitiligo patients' autologous melanocytes transplantation efficiency. PLoS One. 2013;8(4). e60254. doi: 10.1371/journal.pone.0060254. [PubMed: 23577097]. [PubMed Central: PMC3618417]

28. Zhu H, Craig JA, Dyce PW, Sunnen N, Li J. Embryos derived from porcine skin-derived stem cells exhibit enhanced preimplantation development. Biol Reprod. 2004;71(6):1890-7. doi: 10.1095/biolreprod.104.032227. [PubMed: 15306555]

29. Mills AA, Zheng B, Wang XJ, Vogel H, Roop DR, Bradley A. p63 is a p53 homologue required for limb and epidermal morphogenesis. Nature. 1999;398(6729):708-13. doi:10.1038/19531. [PubMed:10227293].

30. Pellegrini G, Dellambra E, Golisano O, Martinelli E, Fantozzi I, Bondanza S, et al. p63 identifies keratinocyte stem cells. Proc Natl Acad Sci U S A. 2001;98(6):3156-61. doi: 10.1073/pnas.061032098. [PubMed: 11248048]. [PubMed Central: PMC30623].

31. Pellegrini G, Ranno R, Stracuzzi G, Bondanza S, Guerra L, Zambruno G, et al. The control of epidermal stem cells (holoclones) in the treatment of massive full-thickness burns with autologous keratinocytes cultured on fibrin. Transplantation. 1999;68(6):868-79. doi: 10.1097/00007890-199909270-00021. [PubMed: 10515389].

32. Jones PH, Harper S, Watt FM. Stem cell patterning and fate in human epidermis. Cell. 1995;80(1):83-93. doi: 10.1016/0092-8674(95)90453-0. [PubMed: 7813021].

33. Jones PH, Watt FM. Separation of human epidermal stem cells from transit amplifying cells on the basis of differences in integrin function and expression. Cell. 1993;73(4):713-24. doi: 10.1016/00928674(93)90251-k. [PubMed: 8500165].

34. Michel M, Torok N, Godbout MJ, Lussier M, Gaudreau P, Royal A, et al. Keratin 19 as a biochemical marker of skin stem cells in vivo and in vitro: Keratin 19 expressing cells are differentially localized in function of anatomic sites, and their number varies with donor age and culture stage. J Cell Sci.1996;109 ( Pt 5):1017-28. [PubMed: 8743949].

35. Yu BD, Mukhopadhyay A, Wong C. Skin and hair: Models for exploring organ regeneration. Hum Mol Genet. 2008;17(R1):R54-9. doi: 10.1093/hmg/ddn086. [PubMed: 18632698].

36. Gallico G3, O'Connor NE, Compton CC, Kehinde O, Green H. Permanent coverage of large burn wounds with autologous cultured human epithelium. N Engl J Med. 1984;311(7):448-51. doi: 10.1056/NEJM198408163110706. [PubMed: 6379456].

37. Ghazizadeh S, Taichman LB. Multiple classes of stem cells in cutaneous epithelium: A lineage analysis of adult mouse skin. EMBO J. 2001;20(6):1215-22. doi: 10.1093/emboj/20.6.1215. [PubMed: 11250888]. [PubMed Central: PMC145528].

38. Takahashi K, Tanabe K, Ohnuki M, Narita M, Ichisaka T, Tomoda K, et al. Induction of pluripotent stem cells from adult human fibroblasts by defined factors. Cell. 2007;131(5):861-72. doi: 10.1016/j.cell.2007.11.019. [PubMed: 18035408].

39. Lowry WE, Richter L, Yachechko R, Pyle AD, Tchieu J, Sridharan R, et al. Generation of human induced pluripotent stem cells from dermal fibroblasts. Proc Natl Acad Sci U S A. 2008;105(8):2883-8. doi: 10.1073/pnas.0711983105. [PubMed: 18287077]. [PubMed Central: PMC2268554]. 